\title{
9
}

\section{Toleration and laïcité}

\author{
Cécile Laborde
}

France is an indivisible, laïque, democratic and social republic. It ensures equality of all citizens before the law with no distinction made on the basis of origin, race or religion. It respects all beliefs.

(Article 2 of 1958 Constitution)

In September 1989, three schoolgirls wearing the traditional Muslim headscarf were barred from entering a school near Paris, and later expelled. The headmaster claimed to be applying a long-established republican rule prohibiting religious symbols in secular state schools. The incident quickly sparked a hotly contested national debate about the principle of religious neutrality in republican schools. A decade later, everything, it seems, has been said about the 'headscarves affair', and the way in which, in quite an exemplary fashion, it crystallised latent national anxieties. These concerned, notably, the contested status of public education in a fragmented society, the problematic legitimacy of traditional norms of authority and social integration, the protracted liquidation of the colonial heritage, fears about a 'conflict of civilisations' pitting the West against 'illiberal' cultures, and a sense of a diffuse but multifaceted threat to French national identity.

Fewer attempts, however, have been made to take seriously the debate surrounding the headscarves affair as a form of philosophical engagement with general principles of toleration, neutrality, and citizenship. ${ }^{1}$ The headscarves debate has generally been perceived as too embedded in a particular socio-political context - too French, in a way - to be compatible with any familiar or plausible understanding of justice and citizenship. This relative neglect of French debates by Anglo-American political theorists undoubtedly stems both from lack of familiarity with the type of political argument favoured in France and from genuinely diverging normative commitments. If we are to make sense of a local debate about justice, such as that surrounding the headscarves affair, we should try to delimit, as far as possible, linguistically mediated misunderstandings from substantive disagreements. 
I take a tentative step in this direction in this chapter through an elucidation of the meaning of the pivotal concept invoked throughout the headscarves debate, laïcité - for which the best (if unsatisfactory) translation remains 'secularism'. Although the word itself did not appear until the end of the nineteenth century, the origins of laïcité are usually traced back to the French revolution, which brutally accelerated a century-long process of autonomisation of the civil government from the Catholic Church. After a century of veiled confrontation and failed compromise between the two institutions, laïcité became the official doctrine of the Third Republic (1870-1940), symbolised by such landmarks as the generalisation of secular state primary education in the 1880 s and the disestablishment of the Catholic Church in $1905 .^{2}$ However, it would be a mistake to reduce laïcité to a conception of the proper relationship between state and religion, with particular attention paid to matters of education. Laïcité is a broader moral and social philosophy, a complex set of ideals and commitments that constitutes the closest equivalent in France - or perhaps direct alternative - to the liberal philosophy of toleration.

In this chapter I suggest that laïcité is a confusing concept because it is internally complex, and appeals to values and concerns that tend to be kept separate in Anglo-American liberal political theory. I identify three main strands of laïcité: neutrality (laïcité A), autonomy (laïcité B), and community (laïcité C). I attempt to situate each of them in the historical context of its emergence, and to offer an analytical elucidation of its relevance to the issues raised by the headscarves affair and to wider debates about toleration. In the conclusion I suggest that the wearing of headscarves in schools was problematic in France because it questioned the normative relevance of all three interpretations of laïcité at the same time. I also raise some questions about the coherence of the concept, and point towards an alternative conceptualisation of laïcité that would do justice to the republican - rather than liberal - language in which it is embedded.

\section{Laïcité as state neutrality}

Laïcité A refers to the institutional separation between church and state. According to the Law of Separation of 1905, 'the state neither recognises nor subsidises any religion' (Article 2). This establishes a regime of mutual independence: freedom of religion (in its individual and collective dimensions) is guaranteed in the private sphere, while state policies are pursued and justified without reference to religious values. Laïcité A is therefore a form of state neutrality. There are, however, two senses in which a state policy can be said to be 'neutral' towards religion. The first, which roughly corresponds to the 'non-establishment' clause of the First Amendment of the US Constitution ('Congress shall make no law respecting an establishment of religion or prohibiting the free exercise thereof') forbids all forms of governmental assistance to any religion. The second, which roughly cor- 
responds to the 'free exercise' clause of the First Amendment, may compel the state to step in to ensure that all groups have effective means to exercise the rights associated with freedom of religion. ${ }^{3}$

The first interpretation of neutrality captures the dominant spirit of the 1905 Separation Law. State abstention, on the lä̈cité A interpretation, is the best way to accommodate the fact of pluralism. By suppressing the privileges enjoyed by the Catholic Church, the Separation Law established the principle of equal treatment between believers, and between believers and non-believers. This principle requires that members of religious minorities, as well as non-religious citizens, not simply be tolerated, but be fully recognised as bearers of the same rights as members of the dominant Church. These rights are universal rights attached equally to all individuals, rather than to groups. The process of institutional dissociation between state and church was thus complemented by the privatisation and individualisation of religion. Catholics were, in a sense, 'refused everything as a nation, and granted everything as individuals', as Jews had famously been during the 1789 revolution. ${ }^{4}$ The neutrality of the state, understood as the privatisation of religious matters, was seen as a guarantee of inclusiveness. All citizens - Catholics and Protestants, Jews and atheists - could identify equally with a shared, non-discriminatory public space where religious beliefs and allegiances were 'bracketed off'. Thus, lä̈cité has recently been defined as 'the political philosophy that best entrenches in law the combination of freedom of conscience and state neutrality'. ${ }^{5}$ Countries where there is an official inequality of treatment between established and non-established religions - such as Britain - or where there is a non-secular public culture such as the US - are seen by advocates of läcité A as falling short of this ideal of neutrality qua abstention. ${ }^{6}$

In practice, however, the Catholic Church has not been reduced to the status of a merely private association in France. The dominant interpretation of läicité A as a strict principle of absolute separation between the state and a wholly 'privatised' church must be qualified. After all, Article 2 of the Separation Law also proclaims that the republic... guarantees the exercise of religious freedom', and such a guarantee can be understood to require an 'active neutrality'. ${ }^{7}$ In practice, the French state does subsidise private religious schools, provide financial help towards the maintenance of religious edifices, respect the internal structure of authority within religious associations, and make possible the exercise of religious liberties in prisons and state boarding schools. 'Active' neutrality, in contrast to 'abstentionist' neutrality, raises tricky issues concerning equality of treatment between religious groups. There are, for example, significant disparities in the degree of state support to 'older' religions such as Christianity and religions such as Islam that have been established more recently in France. ${ }^{8}$ This is because the public funding of religion has in fact rarely been articulated as the consequence of a principled commitment to freedom of religion but was, rather, the outcome of a pragmatic compromise between 
the state and the Catholic Church in $1905 .{ }^{9}$ Prudence and precedent, rather than abstract norms of justice, have underpinned the French policy of active neutrality, which turned out, in practice, to be a policy of active partiality towards the Catholic Church. No wonder therefore that the dominant view of laïcité, that of secular republicans, has been inclined to present the (relatively modest) instances of state funding of religion as an unfortunate exception to, not an application of, the principle of laïcité. ${ }^{10}$ Many Catholics, by contrast, accepted laïcité only in so far as it was defined as an active commitment to the actual exercise of freedom of religion. Abstract liberties, they wryly reminded their opponents on the Left, are not worth having if they cannot be exercised. ${ }^{11}$ Nevertheless, the Catholic attempt at conceptual redefinition failed to displace the dominant philosophical interpretation of laïcite $\mathrm{A}$, that of the separation between the public and the private sphere, and the strict abstention by the state from interference in religious matters.

On this view, the boundaries of the public sphere must be strictly policed, and its secular character preserved, in order for citizens to be able to address one another as equals. In recent years, this interpretation of neutrality as abstention, which was originally elaborated in the context of deep-seated conflicts between state and church, has been extended to the question of the appropriate response to demands for the public recognition of cultural diversity. Laïcité A, in a sense, has become a blueprint for the contemporary management of multiculturalism in France. The neutrality of the state requires that it neither promote nor hamper the expression of religious and cultural identities. Whereas citizens are free to practise their religion and culture within civil society, they should disregard their special memberships in the public sphere. The public sphere, crucially, includes state schools; pupils and teachers are therefore expected to leave behind their particular commitments and identities when they pass the gates of the school. Only then can schools be open to all 'with no distinction made on the basis of opinion or religion', as proclaimed by the 1884 Education Law, which established the principle of free, compulsory and secular primary education. In turn, children are entitled to an education that does not infringe on their private beliefs. Laïcité A, therefore, promotes an 'abstentionist' philosophy of education. In the words of the inspirer of the 1884 law, Jules Ferry, 'the republic stops where conscience begins': teachers have a duty of religious and political neutrality. Not only should they refrain from disturbing the 'sacred conscience' of children but, in addition, they should be careful not to impart values and attitudes likely to offend parental beliefs. ${ }^{12}$ Schools should eschew morally controversial topics and concentrate on the inculcation of so-called 'elementary' notions based on morally neutral, scientific truths. The purpose of public education is to diffuse a corpus of objective knowledge, while 'neutralising all partisan opinions'.

Laïcité A, in sum, offers a broadly liberal response to the problem of toleration, based on a 'wall of separation' between a neutral political sphere 
and the diverse conceptions of the good held by individuals. However, laïcité in France is more than an institutional arrangement designed to accommodate the fact of pluralism. From the start, it was also, perhaps primarily, an attempt to disentangle political institutions from the grip of the Catholic Church, and to substitute democratic civic loyalty for religious and traditional allegiances. In contrast to countries that experienced a slow, incremental process of secularisation, whereby the state progressively shed its non-secular attributes and the established Church slowly relinquished its political and social power to make way for religious pluralism, France experienced the brutal - or at any rate confrontational - assertion of an autonomous civil power struggling to impose a secular, republican order against the claims of religious supremacy made by the Catholic Church. ${ }^{13}$ In the light of this historical heritage, it would be 'reductive' 14 to understand laïcité exclusively through the concern for freedom of religion and state neutrality. From its inception, laïcité was less a consensual compromise than a fighting creed. The separation between public and private implied a distinct re-evaluation of the public sphere, compounded by the relegation of religious beliefs to the private sphere. ${ }^{15}$ Citizens were required, not only to leave behind, but often to transcend, their particularisms by endorsing a superior public identity. Laïcité, therefore, often appealed to a comprehensive liberal ideal of autonomy from religion (laïcité $\mathrm{B}$ ) or to a communitarian concern for civic unity (laïcité C).

\section{Laïcité as promotion of individual autonomy}

Laïcité $\mathrm{B}$ refers to the promotion by the state of the value of secular autonomy, not only in public deliberation but also in the conduct of the good life. It reflects a comprehensive liberal view that the good life consists in autonomy, as well as a perfectionist belief that the state must encourage the pursuit of autonomy-orientated ways of life. Laïcité B differs from laïcité A in claiming to be 'a philosophy of human emancipation', instead of a philosophy of neutrality, ${ }^{16}$ and in explicitly attributing to state education the function of promoting the skills associated with the exercise of autonomy.

Historically, laïcité B can be seen as a stage in the forcible liberalisation of society undertaken by the French state, at a time when republican liberalism was a militant fighting creed rather than the consensual ideology it became during the twentieth century. Liberalising society meant coming into direct confrontation with a conservative Catholic Church, which deemed democratic self-determination an aberration, found repugnant the idea that the identity of the citizen could be separated from that of the believer, claimed to define moral norms for the whole society, and was reluctant to give up its social power - notably in the sphere of education. ${ }^{17}$ It is in a context of strong opposition to established religious authorities that the republicans in power sought to disseminate the principles and practices of 
democratic citizenship. As Claude Nicolet has put it, the republican citizen 'is neither a natural given, nor a product of history. It only exists - in the full sense - through the conquest and exercise of his [or her] reason. ${ }^{18}$ Citizenship consecrated the human capacity for freedom - its ability to shake off all obstacles to the expression of the autonomous rational will. Such sources of heteronomy were diverse, ranging from the holding of unreflected-upon beliefs to blind obedience to traditional authorities, through to instinctive loyalty to particularist groups. The attribution of citizenship, therefore, was conceived as a process of individual emancipation from traditional, oppressive, and obscurantist institutions. Of these, the Catholic Church was the most prominent, and republican citizenship was an instrument of emancipation from religious dogmatism. Individuals were to be encouraged to think of themselves as citizens first, through the inculcation of what the Protestant educationalist Ferdinand Buisson ambiguously called a foi laïque (laïque faith). ${ }^{19}$ Laïcité was like a religion in the etymological sense: it provided a foundation for individual morality and a sense of collective belonging. But this was a non-transcendental, non-clerical religion, which appealed to human reason alone, and substituted for the mystical, conservative and hierarchical ethos of the Church the Enlightenment values of individualism, egalitarianism and rationalism. On this view, progress was identified with the progressive emancipation of human reason from its shackles: ignorance primarily, but also ancestral traditions and unexamined beliefs. As the republican leader Léon Gambetta put it, 'we only have one religion, namely, intellectual culture for all the French' ${ }^{20}$ Only autonomous individuals could be enlightened citizens - hence the crucial autonomypromoting function of state education. That autonomy should be promoted by the state was not seen as a paradox. In the French political tradition, the state shapes, rather than regulates, liberal society, and modern individualism is seen as intimately linked to the civilising power of social and political institutions. ${ }^{21}$ The perfectionist strand of laïcité, therefore, fitted neatly into a tradition less wary of state paternalism than the Anglo-American tradition.

Laïcité B was therefore originally articulated as the official liberal ideology of the French republic. In the early years, however, there was a debate between what we would now call 'political' and 'comprehensive' liberals. The former hoped that laïcité, if construed strictly as a principle of political morality, could be endorsed even by non-liberals - such as traditional Catholics. The challenge was then to define a non-religious moral alternative to religion, which would nonetheless be acceptable to religions. In the words of the sociologist Emile Durkheim, laïque morality should 'seek to capture the truth inherent in every religious or non-religious moral view'22 - for example, a certain conception of the person. To use John Rawls's terms, laïcité should be grounded in an overlapping consensus between reasonable moral doctrines. As for the latter, more 'comprehensive' liberals, they argued, first, that there was a basic incompatibility between republican 
and Catholic world-views and, second, that the state should not refrain from promoting specifically liberal conceptions of the good life, even if these offended non-liberals. In their view, republican laïcité should not be made compatible with religion simply for the sake of stability. Rather, as the Kantian philosopher Renouvier put it, läque morality should explicitly aim to 'take minds away from superstitious beliefs, and above all from doctrines which contradict [the ideal of] justice'. ${ }^{23}$ Under the double influence of Enlightenment critical rationalism and nineteenth-century positivism, many republicans believed that a secular, critically orientated life was more valuable than a religious and conformist one. As political anticlericalism merged with philosophical secularism in the post-Dreyfus years, laïcité became a fighting creed for the promotion of a distinctive conception of human wellbeing. The conservative teachings of the Catholic Church came to be seen as the main obstacle to social and intellectual progress. Religion, in a word, embodied heteronomy. Republicans sought to promote what they called freedom of thought (la liberté de penser) - free rational enquiry and selfdetermination - instead of freedom of conscience (la liberté de conscience) - the freedom to believe whatever one feels inclined to.

In so far as the republicans in power did endorse a more 'comprehensive' than 'political' understanding of läque morality, this was translated almost exclusively - though crucially - into a distinctive philosophy of education. On the republican view, it is the chief mission of state schools to inculcate children with the skills essential to the exercise of autonomy. Now, it is true that in matters of education, the distinction between political and comprehensive liberalism is elusive. ${ }^{24}$ Liberal education promotes individual autonomy without necessarily being ipso facto comprehensively liberal - that is, without controversially promoting a particular conception of the good life. This is for three main reasons. First, education always involves a degree of paternalist authority, because it is addressed to individuals who have not yet formed their conception of the good. Second, education involves inculcating general autonomy-related skills such as the capacity to identify causes and reasons, to exercise critical judgement, to reflect on one's beliefs, and the like. Third, although education may teach the value of choice, it does not have to discriminate between the various ways of life that can be objects of autonomous choice - even if these amount to 'voluntary servitude'. Proponents of laïcité B have often insisted that what matters is not so much the content of the conception of the good held by individuals as the fact that it is autonomously chosen. Lä̈cité is then defined as a 'culture that provides the means to orient oneself freely in the question of [the] meaning [of life]'. ${ }^{25}$ Lä̈que education may encourage children to reflect on the religious beliefs they were brought up with, but does not forbid them from autonomously endorsing them again at the end of a process of careful critical attention. As Claude Nicolet puts it, 'a republican can think what he wishes, provided he thinks by himself'. ${ }^{26}$ On this view, laïcité B does not go beyond providing individuals with the skills associated with the exercise of 
autonomy, that is, it does not stipulate the particular ways in which autonomy may be used to the good.

However, it is undeniable that in its exclusive emphasis on the development of critical skills and its denial that the function of education can in any sense be to preserve children's sense of cultural coherence, laïcité B can be said, ultimately, to involve a comprehensive - rather than narrowly political or instrumental - interpretation of education. Education has more a transformative (or substantive) than a formative (or instrumental) quality. Schools are sometimes presented as the only sphere in which - not only through which - genuine liberty is possible, because they are insulated from the inegalitarian, oppressive structures of civil society. The clearest exposition of laïcité as a comprehensive philosophy of emancipation through education is by a neo-Kantian educationalist, Catherine Kintzler. Writing in the midst of the headscarves affair, she argues that to educate a child is to encourage her to distance herself from her family or community beliefs and to reflect critically on them. As Kintzler puts it, children should 'forget their community and think of something other than that which they are in order to think by themselves'. On this view, social structures essentially alienate individual liberty: only if individuals stand back from received values will they achieve freedom, conceived as rational self-determination. In a society characterised by ubiquitous relationships of domination - cultural, religious and economic - state schools are a privileged locus for the inculcation of the habit of independence through the exercise of critical judgement. ${ }^{27}$ Republican education, Kintzler concludes, is quite literally 'anti-social': it substitutes for non-voluntary forms of social membership a rational capacity for individual self-determination. ${ }^{28}$ On this view, schools should not 'reproduce' social diversity: autonomy is gained, not by exposing children to a range of different ways of life, but by fostering their capacity to abstract from the bonds of social life itself. The near-absence of exposure to basic religious knowledge in French state schools certainly betrays a specific view of the conceptions of the good life that can be the object of legitimate choice.

One should however take the exact measure of the claims made about the emancipatory potential of the republican public sphere. Laïcité B is essentially a philosophy of education: the perfectionist ambitions of the French state, it should be stressed, hardly extend beyond the school gates and the protection of under-age children. Significantly, the legal battle against 'harmful sects' (les sectes nocives) in France has focused on the dangers of the mental manipulation of vulnerable children and adolescents, rarely of adults. The well-publicised 'anti-sect' Vivien Report of 1983, for example, while underlining the risks of 'alienation of moral autonomy' involved in membership of 'irrational' movements, reaffirmed France's central commitment to freedom of conscience and association, and centred its proposals on better information and prevention. Typically, it advocated a reform of laïque education in schools. ${ }^{29}$ So, while it is legitimate for the 
state to foster the capacity for autonomy - through education - the promotion of its actual exercise by mature adults - through paternalist coercion - is found to be hardly compatible with other republican intuitions. Significantly too, autonomy-related arguments were sometimes used to oppose the wearing of headscarves by young Muslim girls, but not by older students or teachers. ${ }^{30}$ Laïcité $\mathrm{B}$, in a word, has stopped short of legitimating an all-out struggle against all forms of heteronomy and domination. Only socialists, from Jaurès onwards, developed an expansive understanding of lä̈cité as a comprehensive philosophy of non-domination. Their laïcité was associated with a progressive, rationalist humanism that promoted a conception of social regeneration and comprehensive emancipation from the reactionary structures both of traditional and modern capitalist society. Laïcité became one integral component of a progressive, militant creed inspired by visions of a transparent, rationally organised, domination-free, self-governing egalitarian society. The official doctrine of laïcité, for its part, rarely questioned structural power relationships in bourgeois civil society, centrally imbued as it was with the Enlightenment view that individual flaws such as ignorance, irrationality and unreasonableness were the only significant obstacles to a 'free' society. Yet despite this narrowly individualist, educationalist and intellectualist bias, long stigmatised by Marxists, there is no denying that lä̈ité B still offers a distinct alternative to the Anglo-American liberal philosophy of toleration. In its commitment to the promotion of individual autonomy, it is centrally concerned with the legitimate limits to toleration, and its advocates often show puzzlement at the idea that the toleration of non-liberal practices of domination can ever be a liberal virtue. Laïcité B, in a word, provides a perfectionist solution to the paradox of liberal toleration.

More in line perhaps with a less perfectionist, more narrowly 'political' liberalism, another justification for autonomy-promoting läque education is its contribution to education for democratic citizenship. Here, a certain level of education is seen as essential to the practice of political deliberation; in Condorcet's terms, it serves to 'enlighten men to make them citizens'. ${ }^{31}$ Historically, this concern for education to citizenship stemmed from the French experience of democracy as a radical experience of selfgovernment. Democracy implies the de-legitimisation of all transcendental or non-rational sources of authority - divine, customary, charismatic - and the exclusive reliance on the will of the citizenry as the only legitimate foundation of power. The 1789 Revolution is often defined as laiqque in this sense. Interestingly, the etymological origin of lä̈cité is the Greek laikos, literally - and as opposed to klerikos - that which characterises the people as a whole, not only a section of it. ${ }^{32}$ Democracy means government by discussion between equal individuals who only recognise the authority of Reason or, as we would say in post-Kantian, post-metaphysical terms, who only wish to be convinced by each others' reasons and to exercise their critical judgement. Education is crucial in inculcating the skills required to be 
able to question the normativity of existing institutions and norms. As Condorcet put it: 'the goal of instruction is not to make men admire a legislation fully completed, but to render them capable of evaluating and correcting it'. ${ }^{33}$ More broadly, laïcité B is often defended as the political counterpart of the commitment to autonomy; as a practice of free, unconstrained democratic deliberation within a 'pluralist public space' that welcomes 'uninterrupted questioning, ${ }^{34}$ A laïque political space is a space of radical collective self-determination, a space whose autonomy it is crucial to protect from the encroachments of non-democratic powers - theocratic, traditional or technocratic. Laïcité B, therefore, establishes a strong connection between individual autonomy and democratic deliberation; in both cases, it reflects a concern to preserve and enhance the human capacity for self-determination - both individual and collective.

\section{Laïcité as civic loyalty}

What I propose to call laïcité $\mathrm{C}$ is undoubtedly the most difficult to grasp, because it is least amenable to liberal thought. The intuition behind it is best captured by the following statement by a contemporary republican philosopher - that 'one cannot be läque in France unless one accepts an important part of our national-republican heritage'. ${ }^{35}$ On this view, laïcité calls not so much for a neutral state respectful of religious difference, nor for a perfectionist state committed to the promotion of individual autonomy, but, rather, for a communitarian state fostering a civic sense of loyalty to a particular historical community. Historically, laïcité $\mathrm{C}$ underlaid the republican ambition to substitute for traditional Catholic-inspired sociability a new civic bond, which would unite citizens in common love of the secular republic. The pro-active policy of laicisation was therefore two-pronged: it simultaneously sought to reduce the pervasive and multifaceted influence of Catholic norms on French society and to anchor the liberal, individualistic principles of the revolution in an alternative republican public culture. The proponents of laïcité $\mathrm{C}$ believed that a nation founded on abstract, disembodied principles of human rights would be quite unable to replicate the level of affective mobilisation achieved by the hegemonic Catholic Zeitgeist. On this view, a society whose only public commitments are to neutrality, individuality or autonomy would be inherently fragile and incapable of sustaining a sense of mutual concern and solidarity between its citizens. In other words, the new laïque civic bond should not be solely based on liberté and égalité: it would also have to inspire feelings of fraternité. Republican society should foster, not the minimal virtue of toleration, but the more demanding virtues of mutual empathy and even altruistic devotion to the community of citizens. Laïcité $\mathrm{C}$ supplements the liberal emphasis with rights and procedures with a concern for the dispositions and attitudes of citizens and the content of the public culture. Abstract citizenship must be complemented with allegiance to a republican 
public culture, which provides the motivational anchorage essential to the legitimacy and stability of a liberal society.

This republican public culture is centred on the cultivation of the traditions and memories of the national civic community. ${ }^{36}$ Since the Third Republic, one explicit purpose of secular, laïque education has been to promote national unity and social cohesion, and to effect the cultural integration of the masses. The regime engaged in an ambitious programme of nation-building that was famously designed to transform 'peasants into Frenchmen' through cultural uniformisation and the diffusion of the values of egalitarian, democratic, patriotic citizenship. ${ }^{37}$ Late eighteenth-century revolutionaries - and a distinguished line of thinkers before and after them, Rousseau and Tocqueville notably - had wondered whether democracy required a civil religion as a functional equivalent to Catholicism. In the course of the nineteenth century, a state-promoted, secularised national identity came to provide this functional equivalent. The elites of the Third Republic, influenced partly by the republican civic tradition and by positivist sociology, sought to establish a new 'civil religion' - as lä̈cité $\mathrm{C}$ is sometimes described to ${ }^{38}$ - complete with founding myths, revolutionary rituals and patriotic celebrations, and promoting an ethically-charged feeling of national belonging and a consensualist conception of democracy. State schools during the Third Republic were often likened to secular churches dedicated to the diffusion of the religion of the patrie. The philosophy of education promoted by advocates of laïcité $\mathrm{C}$ tended to emphasise the centrality of schools in fostering basic moral education, civic loyalty and social conformity, in contrast to läicité B's preferred emphasis on the role of education in promoting 'a-social' individuality, autonomy and critical spirit. ${ }^{39}$

It is, therefore, very fitting that laïcité $\mathrm{C}$ should have been dubbed catholaïcité by its critics. Republican ideology undoubtedly moulded itself to the structures of Catholic society and mentality, only to secularise its symbols and rituals. ${ }^{40}$ Crucially, it also inherited a powerful state tradition permeated by an overriding concern for national unity, a tradition revived by the legacy of the revolution of 1789 , which had in effect destroyed all intermediary groups between state and individuals. The communitarian inspiration of lä̈cité $\mathrm{C}$ cannot be understood unless one takes the measure of this long-standing anxiety towards the individualistic fragmentation of society and the concomitant obsession with social cohesion. Laïcité $\mathrm{C}$ must be interpreted as an explicit attempt to transcend pluralism, mainly through civic education. In today's society, where growing cultural and ethical pluralism has become as much a normative value as a sociological fact, a 'communitarian' education of that sort is bound to raise questions about the extent of the republican tolerance of diversity. As Meira Levinson concisely puts it, 'the French model shifts the brunt of democratic education from teaching toleration of private others to inculcating mutual respect for public similars'. ${ }^{41}$ The question here is whether, by focusing exclusively on 
equal membership in a civic community, laïcité $\mathrm{C}$ actually fosters intolerance of private differences. On the one hand, it must be noted that laïcité C claims to found a liberal community: it, notably, endorses laïcité A's insistence that equal rights must be protected through a rigid separation between the public and the private sphere, as well as laïcité B's emphasis on individuality and autonomy as the central values of the republican public culture. On the other hand, it is undeniable that there is a risk that individuals' differences are in practice swallowed up rather than protected by a homogenising national public character ${ }^{42}$ and that members of minority cultures find themselves forced to assimilate into the ways of life of the majority.

\section{Conceptual coherence in context}

At the end of this inquiry we are in a better position to understand why the wearing of Muslim headscarves in state schools was seen as so problematic in France. This is because, I would suggest, it questioned the normative relevance of laïcité in its three dimensions at the same time. In contrast to other high-profile public debates on laïcité (about the funding of private schools or the content of school curricula, for example) that touched only on one aspect of laïcité, the headscarves affair was exemplary in the complexity of the issues it raised. First, as state schools are seen as extensions of the public sphere, the 'ostentatious' expression of religious belief that headscarves were deemed to represent was interpreted as an encroachment on the neutrality of the public sphere and on the separation between public and private (laïcité A). Second, as veil-wearing is genderspecific and was seen as imposed on the schoolgirls by their parents, it could be construed as a symbol both of inequality and of heteronomy, and therefore as justifying paternalistic state intervention in the interests of the girls (laïcité B). Lastly, in a context of mutual hostility between the French state and sections of the Muslim community (fed by a wave of Algerian fundamentalist terrorism and a general sense of social alienation felt by secondgeneration immigrants) the intrusion of headscarves in schools was interpreted as a symbol of the fragmentation and break-up of society under the centrifugal pressure of multiculturalism (laïcité C). Interestingly, it should be noted, laïcité was also the central concept invoked by advocates of the Muslim girls' position. They too endorsed laïcité A's concern for neutrality, but interpreted it primarily in terms of the entrenchment of the superior principle of freedom of religion. They too invoked the value of individuality and autonomy central to laïcité $\mathrm{B}$, but contested their opponents' definition of what qualifies as an obstacle to autonomy, and pointed out the value of communal membership to individuality. They shared the concern for social unity highlighted by laïcité C, but argued that laïcité should provide a framework for a pluralist social unity, allowing for the mutual recognition of a diversity of cultural groups. In sum, they defended 
'open' laïcité (laïcité ouverte) against the 'hardline' lä̈cité of opponents of veil-wearing. ${ }^{43}$

In quite a striking way, therefore, both advocates and opponents of veilwearing were involved in a multi-layered debate about what may appear to be an essentially shaky concept. For the account given here might be taken to imply that läcité really refers to three different things (neutrality, autonomy, community) that are only confused and conflated in French usage. Yet there is a sense in which my way of recasting the 'headscarves affair' and lä̈cité in general, while it may satisfy the broad intellectual references of Anglo-American liberalism, fails to do justice to the French debate. For, it might be rightly objected, laïcité works in French public discourse precisely as a complex, historically grounded articulation of its various levels of meaning. While the semantic meaning of läicité has always been a matter of intense dispute, the concept is explicitly accepted by all French participants as a useful, relevant and reasonably coherent concept. To conclude, let me venture three brief remarks about the complex issue of conceptual coherence.

First, all political concepts are to some extent contested concepts. ${ }^{44}$ This is most obviously true of laïcité, which has always been a practical slogan rather than an abstract philosophy. Laïcité has never really formed part of an autonomous juridical, political or philosophical theory, isolated from concrete historical moments, and has always been intimately linked to the republican project of the entrenchment of the modern liberal society born out of the French revolution. The semantic meaning of the concept emerged out of political processes of ideological contestation, not out of careful philosophical enterprises of analytical clarification. It is, in fact, a defining feature of political ideologies - of which French republicanism is one - that they tend to accommodate a certain level of conceptual indeterminacy. ${ }^{45}$

Second, the coherence of a concept does to some extent depend on its capacity to make sense of the 'reality' that it claims to describe. The lively debates about laïcité in France undoubtedly reflect growing uncertainty about its contemporary meaning and relevance, an uncertainty that is itself a symptom of the disintegration of the 'republican synthesis' forged under the Third Republic. In the nineteenth century, when nation-building and liberalisation went hand in hand, little tension was felt between the struggle for private freedoms and equal rights (laïcité A), emancipation from traditional and religious identities (lä̈cité B), and the embrace of a new public identity (lä̈cité C). It could even be argued that it is precisely the congruence between the three that has defined modern democratic citizenship. In today's France, the conditions that made possible what Marcel Gauchet calls the convergence between 'the exercise of personal rights and the production of collective unity through the state machine ${ }^{46}$ have all but disappeared. There is now a vast literature on the theme of the 'crisis of laïcité'. ${ }^{47}$ This crisis is rooted in a number of complex recent trends: the collapse of comprehensive ideologies (notably laïcités main adversary, Catholicism), 
the displacement of citizenship as individuals' central identity, the rise of consumerist individualism, the discredit of shared public moralities, the broad questioning of Western universalist rationalism, growing pluralism and demands for the recognition of difference, and the multifaceted crisis of the nation. It is in this context that the tensions intrinsic to the concept of laïcité - between state neutrality and state perfectionism on the one hand, and between individual autonomy and civic loyalty on the other - are most acutely felt.

Third, the possibility must at least be raised that such conceptual tensions are, at least in part, embedded in the analytical language that has been used to make sense of French laïcité throughout this chapter. I have explicitly sought to 'translate' French debates into the language of AngloAmerican liberal philosophy, using such concepts as state neutrality, political and comprehensive liberalism, autonomy-promoting perfectionism, universalist and communitarian ethics. Such conceptual combinations have suggested an analytical decomposition of laïcité into three distinct components, and allowed a more rigorous understanding of its political implications. It might be the case, however, that these conceptual combinations also hide from view other semantic connections, which might be absent from the ordinary (English) language in which analytical philosophy is rooted, but central to alternative political philosophies. After all, the dominant language of politics in France is republicanism, not liberalism (even if republicanism has historically occupied the ideological space of liberalism). If we recast laïcité in ways that make it consistent with the distinct understanding of liberty favoured by French (liberal) republicans - liberty as non-domination - we might be able to soften some of the tensions that exist between its three analytical components of neutrality, autonomy and community. The contradiction between laïcité A's commitment to equal rights and freedom of religion and laïcité C's commitment to a statepromoted public culture, for example, dissolves if it is conceded that liberty is not a 'natural' condition but a fragile social status that must be upheld by public institutions. Similarly, the tensions between the ideals of comprehensive emancipation (laïcité B) and state neutrality (laïcité A) can be eased somewhat if neutrality (and laïcité) is seen as an ideal of nondomination rather than an ideal of non-interference. Clearly, more needs to be done to specify the conceptual ways in which a republican account can transcend the dichotomies that permeate liberal analytical political philosophy. Such a project is inevitably driven by conflicting objectives. On the one hand, it must strive to be faithful to existing understandings as they are embedded in particular discursive traditions (in my case, the tradition of French republicanism). On the other hand, it must be made commensurable with other languages, notably that of Anglo-American liberalism. Whether these two concerns - intelligibility and integrity - can be balanced and reconciled is the central problem of cross-cultural theory. 


\section{Notes}

Research for this project was funded by a Research Grant from the School of Humanities, King's College London, for which I am grateful. A version of this chapter was published in Constellations. An International Journal of Critical and Democratic Theory, Vol. 9 (2002). I am grateful to the editors and to Blackwells for permission to republish material for this article.

1 Two exceptions in English are: M. Levinson, 'Liberalism versus democracy? Schooling private citizens in the public square', British Journal of Political Science, 27 (1997) 333-60; and E. Galeotti, 'Citizenship and equality. The place for toleration', Political Theory, 21:4 (1993) 585-605.

2 See J. Baubérot, Histoire de la laïcité française (Paris: Presses Universitaires de France, 2000). For a historical overview in English, see K. Chadwick, 'Education in secular France: (Re)defining laïcité', Modern and Contemporary France, 5:1 (1997) 47-59.

3 This distinction, which is inspired by V. Bader ('Religious pluralism. Secularism or priority for democracy?', Political Theory, 27:5 (1999) 597-633, at p. $605)$, is in my view clearer than M. Barbier's distinction between 'separation', 'neutrality' and 'impartiality' in La Laïcité (Paris: L'Harmattan, 1995), pp. $84-8$.

4 According to the famous phrase of Clermont-Tonnerre, cited in Pierre Rosanvallon, Le Sacre du Citoyen. Histoire du suffrage universel en France (Paris: Gallimard, 1992), p. 76.

5 J. Costa-Lascoux, 'La laïcité au défi du multiculturalisme', in Jean-Michel Lecomte and Jean-Pierre Sylvestre (eds), Culture républicaine, citoyenneté et lien social (Dijon: CNDP, 1997), pp. 213-25, p. 221.

6 See J. Zylberberg, 'Laïcité, connais pas: Allemagne, Canada, Etats-Unis, Royaume-Uni', Pouvoirs, 75 (1995), pp. 37-52. For a more sceptical evaluation of French 'exemplarity' (in the two senses of the term) see J. Baubérot, 'La laïcité française et l'Europe', Philosophie Politique, 4 (1991) 89-100.

7 See the good survey of Jean-Michel Lemoyne de Forges, 'Laïcité et liberté religieuse en France' in Joël-Benoït d'Onorio, La liberté religieuse dans le monde. Analyse doctrinale et politique (Paris: Editions Universitaires, 1991), pp. 149-70; the legal analyses of J. Robert, 'La notion juridique de laïcité et sa valeur constitutionnelle', in H. Bost (ed.), Genèses et enjeux de la laïcité. Christiannismes et laïcité (Paris: Labor et Fides, 1990), pp. 89-100; R. Drago, 'Laïcité, neutralité, libertée', Archives de Philosophie du Droit, 38 (1993) 221-30; and F. Messner, 'Laïcité imaginée et laïcité juridique', Débat, 77 (1993) 88-94, which points to a gap between the strict 'ideological' interpretation of the separation of state and religion and the widespread practice of public subsidies to religious associations.

8 S. Pierré-Caps, 'Les “nouveaux cultes” et le droit public', Revue de droit public, 4 (1990) 1073-119.

9 For interpretations of the Separation Law as a 'tolerant' law, see J. Robert, 'La notion juridique de la laïcité et sa valeur constitutionnelle', pp. 89-100; J. Baubérot, Vers un nouvean pacte laïque? (Paris: Seuil, 1990); La morale lä̈que contre l'ordre moral (Paris: Seuil, 1997); J. Boussinesq, La laïcité française. Mémento juridique (Paris: Seuil, 1994), pp. 47-56. 
10 Most of the conflicts over laïcité - which broadly defined the battle-lines between left and right in France - concerned the state funding of private (religious) schools. The traditional laïque battle-cry about education is: 'state funds for state schools, private funds for private schools'.

11 See J. Rivero, 'La notion juridique de laïcité', Chronique du Recueil Dalloz, 31 (1940) 137-40.

12 J. Ferry, 'Lettre aux instituteurs' (27 November 1883), Pouvoirs, 75 (1995) 109-16, at p. 111. For a legal analysis of neutrality in schools, see A. Thiriot, 'Le principe de neutralité et l'enseignement', Savoir - Education - Formation, 3 (1993) 403-23.

13 For a comparative perspective, see F. Champion, 'Entre laïcisation et sécularisation. Des rapports Eglise-Etat dans l'Europe communautaire', Le Débat 77 (1993) 46-63.

14 M. Barbier, La laïcité (Paris: L'Harmattan, 1995), p. 30.

15 M. Gauchet, La religion dans la démocratie. Parcours de la laicité (Paris: Gallimard, 1998).

16 P. Hayat, La laïcité et les pouvoirs. Pour une critique de la raison lä̈que (Paris: Kimé, 1998), p.130.

17 Y. Deloye, Ecole et citoyenneté. L'individualisme républicain de Jules Ferry à Vichy (Paris: Presses de la Fondation Nationale des Sciences Politiques, 1994).

18 C. Nicolet, L'idée républicaine en France (1789-1924). Essai d'histoire critique (Paris: Gallimard, 1994), p. 483.

19 Cited in P. Macherey, 'Philosophies laïques', Mots, 27 (1991) 5-21, at p. 18.

20 Ibid.

21 Rosanvallon, L'Etat en France (Paris: Seuil, 1990), pp. 93-135.

22 Emile Durkheim, cited in Gauchet, La religion dans la démocratie, p. $50 \mathrm{n} 1$.

23 Charles Renouvier, cited ibid., p. 49.

24 For the developments that follow, I have (freely) drawn on A. Gutmann, 'Civic Education and Social Diversity', Ethics, 105 (1995) 557-79; V. Muñoz-Dardé, 'Condorcet, Liberal Education and Ethical Pluralism', unpublished manuscript (on file with the author); and M. Levinson, The Demands of Liberal Education (Oxford: Oxford University Press, 1999).

25 G. Coq, Laïcité et république. Le lien nécessaire (Paris: Edition du Félin, 1995), p. 156.

26 Nicolet, L'Idée républicaine en France, p. 503. See also C. Kintzler, 'Aux fondements de la laïcité scolaire. Essai de décomposition raisonnée du concept de laïcité', Les Temps Modernes, 527 (1990) 82-90.

27 C. Kintzler, La République en questions (Paris: Minerve 1996), pp. 78-81, p. 85; 'Aux fondements de la laïcité scolaire', pp. 88-90.

28 Kintzler, La République en questions, pp. 18, 88, and 109. See also R. Debray, 'La laïcité: une exception française', in Bost, Genèses et enjeux de la laïcité, pp. 199-208; and in Charles Coutel (ed.), La République et l'école. Une anthologie (Paris: Presses Pocket, 1991), J. Muglioni, 'Philosophie, école, même combat?' pp. 74-80 and Jean-Louis Poirier, 'Troisième République', pp. 65-71; and A. Prost, 'La République et l'école', Projet, 213 (1988), pp. 85-95. For a critique of this conception of schools, see F. Lorcerie, 'L'école pourrait être un laboratoire de civilité' in Hommes et Migrations, pp. 1129-30 (February-March 1990), pp. 41-2.

29 A. Vivien, Les Sectes en France. Expression de la liberté morale ou facteurs de 
manipulation? Rapport au Premier Ministre (Paris: Documentation Francaise, 1983), esp. pp. 25ff., pp. 111ff. Significantly too, in a 1992 ruling, the Council of State ruled that no breach of state neutrality or freedom of religion was involved in the government's decision to subsidise an anti-Church of Scientology association, in light of the risks posed by the sect, 'notably for young people'. See R. Drago, 'Laïcité, neutralité, liberté?', Archives de Philosophie du Droit 38 (1993) 221-30. The broadly tolerant treatment of sects by French law is well-documented in Stéphane Pierré-Caps, 'Les "nouveaux cultes" et le droit public', Revue de droit public, 4 (1990) 1073-119.

30 It was widely held that teachers should avoid displaying symbols of religious allegiances, but this was justified by a neutrality-based argument (laïcité A), not by an autonomy-related one (laïcité B). For a discussion, see Thiriot, 'Le principe de neutralité et l'enseignement'.

31 On Condorcet, see C. Kintzler, Condorcet. L'instruction publique et la naissance du citoyen (Paris: Minerve, 1984).

32 José Bory, 'D'une conception tolérante de la laïcité à la reconnaissance d'un droit d'ingérence des Etats', Administration, 177 (1997) 82-90.

33 Condorcet, Premier mémoire sur l'instruction publique (extract) in Coutel, La République et l'Ecole. Une anthologie, p. 176.

34 E. Morin, 'Le nouveau combat de la laïcité', Le Débat, 58 (1990) 40-1. See also, for a reading of laïcité inspired by Habermas's discourse ethics, P. Hayat, La laïcité et les pouvoirs. Pour une critique de la raison lä̈que (Paris: Kimé, 1998), Chapter 4.

35 Jean-Pierre Sylvestre, 'Les fondements de la conception laïque du lien social', Raison Présente, 122 (1997) 79-96, at p. 91.

36 Sylvestre, ibid., p. 91.

37 E. Weber, Peasants into Frenchmen (Stanford, CA: Stanford University Press, 1976); Ernest Gellner, Nations and Nationalism (Ithaca, NY: Cornell University Press, 1983).

38 See, for example, Jean-Louis Willaime, 'La religion civile à la française et ses métamorphoses', Social Compass, 40:4 (1993) 571-80; J. Roman, 'La laïcité comme religion civile', Esprit, 175 (1991) 108-15.

39 On this point see J. Baubérot, 'Aux fondements de la laïcité scolaire. Réponse à Catherine Kintzler', Les Temps Modernes, Jan.-Feb. (1991) 163-71.

40 See J. Carbonnier, 'La culture française: une culture “catholique” laïcisée?', Parole et Société, 34 (1993) 173-87; Jean-Louis Willaime, 'La religion civile à la française et ses métamorphoses'.

41 Levinson, 'Liberalism versus democracy?', p. 353.

42 Ibid.

43 For a critical approach to the terms of this debate, see E. Balibar, 'Faut-il qu'une laïcité soit ouverte ou fermée?', Mots, 27 (June 1991) 73-9.

44 W. B. Gallie, 'Essentially contested concepts', Proceedings of the Aristotelian Society, 56 (1955-56) 167-98.

45 M. Freeden, Ideologies and Political Theory. A Conceptual Approach (Oxford: Oxford University Press, 1996), Chapter 2.

46 M. Gauchet, 'L'école à l'école d'elle-même. Contraintes et contradictions de l'individualisme démocratique', Le Débat, 36 (1985) 55-78.

47 R. Rémond, 'La laïcité n'est plus ce qu'elle était', Etudes, 360:4 (1984) 439-48; J. Baubérot, Vers un nouveau pacte lä̈ue?; M. Gauchet, La religion dans la 
démocratie; Françoise Lorcerie, 'Dissonance normative. A propos de la crise de la laïcité en France', Printemps, 2 (1996) 7-20; Jean-Louis Schlegel, 'Laïcité et religion dans la société française d'aujourd'hui', in Catherine Wihtol de Wenden (ed.), La citoyenneté (Paris: Fondation Diderot, 1988), pp. 295-306. For an extensive survey of the recent debates on laïcité, see P. Ognier, 'Ancienne ou nouvelle laïcité? Après dix ans de débats’, Esprit, 194 (1993) 202-21. 